\title{
A NEW UNDERWING MOTH FOR THE PRAIRIE PROVINCES
}

RONALD R. HOOPER, Saskatchewan Museum of Natural History, 2340 Albert Street, Regina, Saskatchewan. S4P 3V7

On 11 September 1990, one mile west of Fort Qu'Appelle, I had just observed a Whooping Crane flying high in the sky, near some Sandhill Cranes. I went for the binoculars to get a better look. When I returned I couldn't find the crane, but I found another rarity.

On the shingled wall where the light had been shining the previous night, I saw a "different" looking underwing moth. It turned out to be the Western Underwing (Catocala aholibah - Strecker). I had a photograph of it identified by Dr. Lawrence Gall of the Peabody Museum of Natural History, New Haven, Connecticut.

The food plant of the Western Underwing is Garry Oak which occurs in Canada only in southwestern British Columbia and Vancouver Island. It ranges southeastward to Colorado. The range of the Western Underwing is approximately that of its food plant. It has, however, been taken northeastward to westem South Dakota, western North Dakota, and now Fort Qu'Appelle, Saskatchewan. It is assumed that the specimens taken outside the range of the known food plant are strays.

The rosy red hind wings are edged with a broad black outer border which appears to have a saw-toothed outer edge. This is caused by the row of small white triangles along this border. No other species of Underwing Moth in North America shows this feature so clearly.

This brings the present list of Underwing moths for Saskatchewan to 17 species.

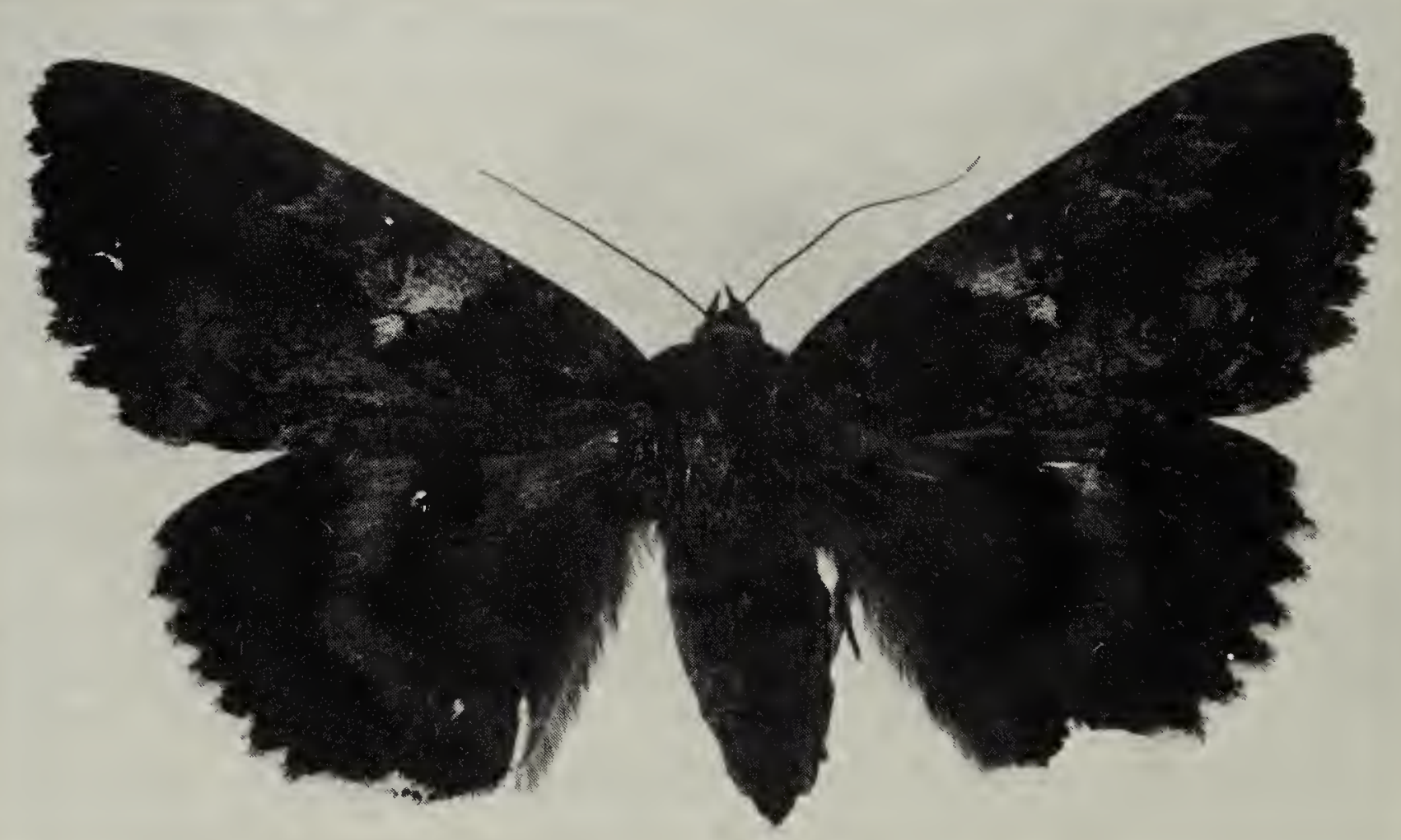

